\title{
Semenov A., INFLUENCE OF PRE-SOWING UV-RADIATION Kozhushko G., ON THE ENERGY OF GERMINATION CAPACITY AND GERMINATION ABILITY OF RAPESEED
}

Об'єктом дослідження є насіння ріпаку, що за об'ємами посіву займає перше місие серед олійних культур. Одним з найбільи проблемних місиь сільськогосподарського комплексу є збільшення кількості та якості насіннєвого матеріалу. Для вирішення даної проблеми вчені та фахівці сільського господарства використовують різні методи, віддаючи перевагу оптичному випромінюванню - передпосівна УФ-обробка насіння. Вибір режимів обробки вимагає проведення детальних досліджень та диференційованого підходу для кожної сільськогосподарської культури окремо.

В роботі досліджено передпосівний вплив ультрафіолетового УФ-опромінення насіння ріпаку на біологічні процеси (енергія проростання, схожість та зростання). В ході дослідження використовувалися ультрафіолетові лампи низького тиску потужністю 20 Bm, типу ZW20D15W (Китай), що випромінюють в області С. Вимірювання дози опромінення проводили згідно стандартних методик за допомогою радіометра «Тензор-31» (Україна).

Зразки насіння рапсу, крім контрольних, опромінювали ультрафіолетом в області С дозами: 10 Дж/м²,

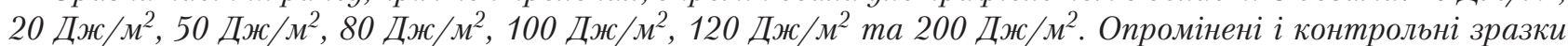
насіння пророшували в чашках Петрі при температурі повітря $24 \pm 2{ }^{\circ} \mathrm{C}$. Облік кількості проростків насіння проводили через 3 доби - енергія проростання, а через 7 діб - схожість.

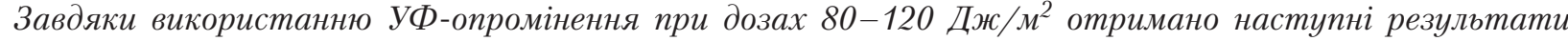
в порівнянні з контрольним зразком: енергія проростання насіння ріпаку збільшується на 20-26\%; схожість збільшується на 16 \%. При цьому середня біомаса рослин із опроміненого насіння за 10 днів зростання збільшується в порівнянні з контрольними зразком на 18,3\%.

При польових дослідженнях схожість насіння ріпаку після опромінення дозою УФ-С 120 Дж/м в в порівнянні з контрольним зразком збільшилась на $16 \%$ і стала $89 \%$.

Ключові слова: УФ-опромінення, доза опромінення, передпосівна обробка насіння, енергія проростання, схожість насіння ріпаку.

\section{Introduction}

Rapeseed is a strategically important culture, as it occupies an important place in the food and energy balance of the state. Rapeseed oil, thanks to its unique biological properties, is widely used not only in the food industry, but in many branches of the economy [1-3].

Rapeseed has an important value as a valuable crop for the cultivation of green fodder for farm animals. The smell of green mass as a sideral fertilizer is equivalent to applying 15-30 tons per 1 ha of manure. Raising rapeseed improves the balance of rubber in crop rotation with most cereals. As a precursor of rapeseed, it is possible to reduce the costs of soil cultivation and plant protection products. Rapeseed is of great importance as honey rapeseed flowers are attractive and easy to collect nectar, its flowering lasts from 25 to 30 days. This provides a large collection of honey - up to $90 \mathrm{~kg}$ per hectare, and sometimes much more.

Increasing the quantity and quality of crop production is the main task in the development of the agricultural complex. The central link in solving this problem is seed production. Seeds, the carrier of biological properties, determine decisively the quality and quantity of the crop. Scientists and agricultural specialists are constantly im- proving and developing new agro-activities and technical means for pre-sowing seed stimulation in order to improve their sowing quality [4-6]. Providing high crop yields at optimal costs and high-quality seed indicators, as well as mastering technologies for obtaining new types of rapeseed products, are important tasks for the agro-industrial complex for the near future.

One of the effective ways to improve the quality of the seed is influencing the seeds by physical factors: heating [7], the effect of ionizing gamma rays [8]. In agricultural practice, various methods of pre-sowing seed treatment are used - electrical [9] and magnetic fields [10] and electromagnetic radiation [11]. In [12], the influence of the degree of uneven heating of seeds in the electromagnetic field of ultrahigh frequency on their germination energy and germination was investigated.

Seed pre-sowing treatment using electrophysical methods was considered in [13, 14]. Back in the mid-1980s, gas neon and helium lasers were used for pre-sowing seed treatment. Irradiation of barley seeds with red light at a wavelength of $754 \mathrm{~nm}$ causes an increase in productive bushiness by $37.2 \%$ and a stalk length of $7 \mathrm{~cm}$ [15]. The amount of irradiation energy and the time of seed treatment are different for each culture, so the choice of treatment regime requires a differentiated approach [16]. 
The use of UV irradiation is of great interest for stimulating growth and increasing the resistance of plants to external factors and increasing the yield of crops [17, 18]. Investigation of the influence of pre-sowing irradiation of plant seeds with ultraviolet radiation on their growth, productivity, infection with fungal and other diseases has been initiated for a long time, but this problem has not been studied thoroughly enough, therefore, studies in this direction are topical.

In preseeding processing of seed material of agricultural enterprises of UV-irradiation cultures on biological processes, the effect is twofold: there is an increase or decrease in germination energy, germination and germination capacity.

Study of the influence of ultraviolet irradiation on the seeds of various crops in the pre-sowing processing, including rape, is actual.

\section{The object of research and its technological audit}

The object of research is the winter rapeseeds of the 2017. Rapeseed among the oilseeds of the cabbage family ranked first in oil content, as well as a valuable crop for the production of biofuels.

One of the most problematic places of the agricultural complex is an increase in the quantity and quality of the seed material. Rape seeds need an average of 3 to 10 days for germination, and at this time it is particularly sensitive to pathogenic microorganisms that are the causative agents of infections and diseases.

A great interest for raising seeds to external factors and stimulating growth and increasing yields is the treatment of seeds of crops with ultraviolet radiation. This allows to reduce the use of fungicides or even abandon them.

\section{The aim and objectives of research}

The aim of research is studying the pre-sowing effect of ultraviolet (UV) seed irradiation on biological processes (germination energy, germination and growth) in laboratory and field conditions.

To achieve this aim, it is necessary to perform the following tasks:

1. Irradiate seeds with UV radiation in the area with artificial light sources.

2. Determine the necessary dose of pre-sowing seed treatment with UV irradiation in terms of: germination energy and seed germination.

3. Calculate the energy of germination ability and germination capacity of seeds. Compare the obtained results for irradiated samples with control samples.

4. Conduct comparative studies of plant biomass after 10 days and plant height after 12, 25 days of growth in field conditions for control samples with irradiated seed samples.

\section{Research of existing solutions of the problem}

Germination ability is the main indicator of seed quality [18]. For this purpose, the seed material is subjected to various means of action, where the leading role belongs to energy, activates the germination of seeds and strengthens the vital activity of the embryo at the initial stage [19].
As shown by the analysis of literature sources of existing methods of electromagnetic influence on seeds before sowing, UV irradiation is of the greatest interest [20-22]. Treatment of the pre-sowing material with bactericidal UV radiation in the $\mathrm{C}$ region not only increases the germination energy and seed germination [23], but also disinfects it [19].

The positive effect of pre-sowing seed treatment by UV radiation is noted in [23]: the germination energy and field germination of seeds are increased, which ensures stable yields of ornamental crops. It is shown in [24, 25] that irradiation of UV-C seeds of wheat stimulated its germination. But, in spite of these studies, the question of determining the rational range of ultraviolet exposure in different energy areas and radiation doses, of different crops, including rape, continues to be undefined.

Pre-sowing UV irradiation of seeds creates a complex of effects - increasing the energy of germination ability and germination capacity [26, 27]. It also stimulates growth processes, increases the stress tolerance of plants [22] and disinfects seeds from pathogens [24]. This allows to reduce the use of pesticides, reduces the concentration of pesticides in the soil and improves the quality of crop production and its yield [28].

Thus, the results of the analysis make it possible to assert that the most important effect that UV irradiation creates upon pre-sowing treatment is an increase in the energy of germination ability and germination capacity [26, 27, 29].

\section{Methods of research}

The germination ability energy and seed germination capacity are carried out in laboratory conditions according to the methods according to [30]. These values are compared for seeds irradiated with different doses of UV-C with control samples (without irradiation). By germination energy is meant the percentage of sprouted seeds in 72 hours, and the germination of seeds is the percentage of germinated seeds in 7 days.

Samples for the study are selected from the consignment of rapeseed in accordance with the requirements of [30].

Pre-collected seed samples are tested for CP4 EPSPS protein, the presence of which indicates a gene modification of the rape variety. The test set AgraStrip RUR-HS from ROMER Labs (Austria) is used for testing [31]. The analysis is carried out in accordance with the GAFTA 124 Grain and Feed Trade Association standard [32].

200 seeds for a control sample and 200 seeds for irradiation with different doses of UV-C are passed for the experiments.

The seeds are laid out on several layers of moistened filter paper in Petri dishes and kept in a thermostat at a temperature of $7 \pm 2{ }^{\circ} \mathrm{C}$ for 1 day. Further cooled samples (except control ones) are irradiated with UV-C doses of $10 \mathrm{~J} / \mathrm{m}^{2}, 20 \mathrm{~J} / \mathrm{m}^{2}, 50 \mathrm{~J} / \mathrm{m}^{2}, 80 \mathrm{~J} / \mathrm{m}^{2}, 100 \mathrm{~J} / \mathrm{m}^{2}, 120 \mathrm{~J} / \mathrm{m}^{2}$ and $200 \mathrm{~J} / \mathrm{m}^{2}$.

For exposure, a low-pressure UV lamp of the type ZW20D15W (China) with a power of $20 \mathrm{~W}$ is used [33]. The distance from the lamp to the seed samples is $0.25 \mathrm{~m}$. The UV-C radiation is measured using a Tenzor-31 (Ukraine) radiometer using the procedure [34].

Irradiated and control samples of the seeds are germinated in Petri dishes at an air temperature of $24 \pm 2{ }^{\circ} \mathrm{C}$. The first appearance of seedlings (energy of germination) is carried out after 3 days, and the germination rate after 7 days. 


\section{Research results}

In laboratory conditions, studies are carried out on growing plants after UV irradiation with a dose of $120 \mathrm{~J} / \mathrm{m}^{2}$ in a special soil - the «universal» substrate [35], which includes all the necessary macro- and microelements. The air temperature in the room is kept within $24-26{ }^{\circ} \mathrm{C}$ with a relative humidity of $60-75 \%$. The growth cycle to the control measurement is 10 days.

In addition to laboratory studies, field studies of the similarity of the same lot of rapeseed and its growth in the first days of development in the conditions of open ground are conducted. The similarity of irradiated seeds with a dose of $120 \mathrm{~J} / \mathrm{m}^{2}$ and the biomass of the terrestrial part was compared with the control unirradiated sample.

The research results are shown in Fig. 1 and are summarized in Tables 1, 2.

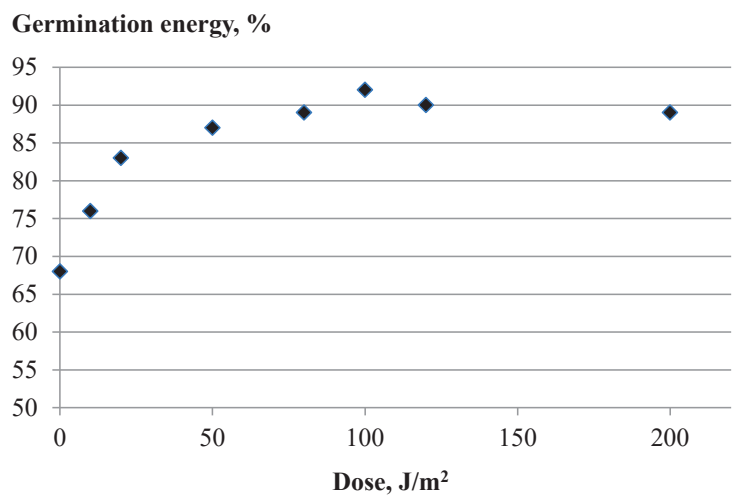

Fig. 1. Energy of rapeseed germination after irradiation

Tahle 1

The energy of germination of irradiated and control seed samples

\begin{tabular}{|l|c|c|c|c|}
\hline \multicolumn{1}{|c|}{ Sample characteristic } & \multicolumn{5}{|c|}{$\begin{array}{l}\text { The energy of seed germi- } \\
\text { nation in each sample from } \\
100 \text { grains, \% }\end{array}$} \\
\hline 1. Control sample & 26 & 24 & 32 & 30 \\
\hline 2. The sample irradiated with a dose of $\mathrm{J} / \mathrm{m}^{2}$ & 48 & 42 & 52 & 46 \\
\hline
\end{tabular}

Table 2

The average amount of biomass of rapeseed plants after 10 days of growth at different doses of UV irradiation

\begin{tabular}{|l|c|c|}
\hline \multicolumn{1}{|c|}{ Sample } & Irradiation dose, $\mathrm{J} / \mathrm{m}^{2}$ & Amount of biomass, \% \\
\hline Control & - & 100 \\
\hline \multirow{3}{*}{ Irradiated } & 50 & 111.1 \\
\cline { 2 - 3 } & 120 & 118.3 \\
\cline { 2 - 3 } & 240 & 2 \\
\hline
\end{tabular}

The results of analysis of the rapeseed sample, according to [32], show the absence of the CP4 EPSPS protein, indicating a rape variety that is not genetically modified.

Research results of rapeseed germination energy as a function of the dose of UV-C irradiation (Fig. 1) show that at doses of $80-100 \mathrm{~J} / \mathrm{m}^{2}$, the germination energy increases by $20 \div 26 \%$ in comparison with the control sample, and the similarity by $16 \%$. In this case, the average biomass of plants from irradiated seeds increases by $18.3 \%$ in comparison with the control sample for 10 days of growth (Table 2).
In field studies, the germination of rape seeds after irradiation with a UV-C dose of $120 \mathrm{~J} / \mathrm{m}^{2}$ compared to the control sample increased by $16 \%$ and becomes $89 \%$. The height of plants from irradiated seeds on the 12th day of growth exceeded control samples by $7 \%$, and by day 25 - by $5 \%$. Moreover, the height of the ground portion of plants from irradiated seeds on day 12 is $13 \%$ (at $29 \%$ for the control sample), and on day 25, respectively, $8 \%$ and $16 \%$.

\section{SWOT analysis of research results}

Strengths. Studies have shown that UV irradiation in doses of $80-120 \mathrm{~J} / \mathrm{m}^{2}$ positively affects the most important indicators of seed material: germination ability and germination energy, since the increase in these values is $16-20 \%$.

In the field, there is a positive UV effect on the development of the terrestrial part, since the irradiated seeds germinate faster. And in the future, with its growth after 10 days and after 25 days, the average value of the length of the ground part of plants exceeds the height of the control unirradiated samples by $5-7 \%$.

The effectiveness of ultraviolet irradiation of seeds in comparison with other methods of stimulation of growth processes is low energy consumption: the cost of electricity amounted to $0.0005 \mathrm{~kW}$ per $1 \mathrm{~kg}$ of seed. The processing time for the samples is $60 \mathrm{~s}$ when irradiated with a dose of $120 \mathrm{~J} / \mathrm{m}^{2}$.

The cost of the pilot installation for the work is 35.5 USD. The design of the installation takes into account modern technical solutions for the development of such devices:

- electrical circuit with electronic starting equipment;

- a non-zoned ultraviolet lamp with a high efficiency in the UV region - $30 \%$ of the rated power. Lamps of this type are successfully used for bactericidal disinfection of drinking water [36] and air [37].

Pre-sowing treatme nt of seeds UV-C can find practical use in growing plants without the use of chemicals, growth stimulants. This is a promising area in the field of agriculture, since it makes it possible to reduce the amount of fungicides in the pre-sowing treatment or to abandon them altogether.

Weaknesses. One of the negative aspects of pre-sowing UV irradiation of seed material is that it is necessary to take into account the safety requirements: protection against direct and reflected ultraviolet rays from entering the personnel and others.

Opportunities. In the future, it is planned to conduct research on irradiation of seeds with UV radiation in other energy regions $\mathrm{B}$ and $\mathrm{A}$. This will make it possible to compare plant growth parameters in various regions of the ultraviolet spectrum and to carry out calculations of the necessary costs in each experiment.

Threats. Additional costs are required for pre-sowing plant stimulation with UV irradiation, but they are compensated for by increasing the yield and reducing the number of chemicals used in the pre-sowing treatment.

\section{Conclusions}

1. Low-pressure ultraviolet lamps with a range of ultraviolet radiation of $200-280 \mathrm{~nm}$ are used for pre-sowing irradiation of rapeseeds. 
2. Rapeseeds are irradiated with doses of $10 \mathrm{~J} / \mathrm{m}^{2}$, $20 \mathrm{~J} / \mathrm{m}^{2}, 50 \mathrm{~J} / \mathrm{m}^{2}, 80 \mathrm{~J} / \mathrm{m}^{2}, 100 \mathrm{~J} / \mathrm{m}^{2}, 120 \mathrm{~J} / \mathrm{m}^{2}$ and $200 \mathrm{~J} / \mathrm{m}^{2}$. It is found that at a dose of UV radiation of $80-120 \mathrm{~J} / \mathrm{m}^{2}$ the percentage of sprouted seeds (germination energy) increased by $5-15 \%$ compared to samples of seeds irradiated with smaller or larger doses.

3. The results of calculating the germination energy and seed germination showed that, at doses of $80-120 \mathrm{~J} / \mathrm{m}^{2}$, the germination energy increases by more than $20 \%$, and the similarity by $16 \%$ compared to the control samples.

4. In determining the biomass of plants, it is found that its quantity on the 10th day of growth is $18 \%$ higher for irradiated samples than for control samples, and the height of plants for 12 days and 25 days for growth is 5 and $7 \%$, respectively.

\section{References}

1. Kiver V. Kh., Amroziak Yu. V., Maslikova K. P. Ripak u Pivnichnomu Stepu Ukrainy: znachennia, spektr vykorystannia ta perspektyvy vyrobnytstva // Visnyk ahrarnoi nauky Prychornomoria. Spetsvypusk. 2006. Vol. 1, Issue 4. P. 101-105.

2. Tokarchuk D. M. The modern state, efficiency and prospects of rape production in the european union and in Ukraine Ahrosvit. 2015. Issue 13. P. 19-23.

3. Dankevych Ye. M. Perspektyvy rozvytku mizhhaluzevoi intehratsii u haluzi ripakivnytstva // Stalyi rozvytok ekonomiky. 2013. Issue 4. P. 296-299.

4. Shapar L. V. Nasinnieva produktyvnist sortiv ripaku ozymoho zalezhno vid strokiv sivby ta norm vysivu $\mathrm{v}$ umovakh pivdennoho stepu Ukrainy: PhD thesis. Kherson, 2017. 219 p.

5. Harbar L. A., Antal T. V. Romanov S. M. Osoblyvosti formuvannia produktyvnosti posiviv ripaku yaroho za vplyvu norm vysivu ta udobrennia // Visnyk Poltavskoi derzhavnoi ahrarnoi akademii. 2016. Issue 4. P. 24-26.

6. Lavrynenko Yu. O., Vlashchuk A. M., Shapar L. V. Vplyv strukturnykh pokaznykiv na urozhainist nasinnia ripaku ozymoho zalezhno vid strokiv sivby ta norm vysivu v Pivdennomu Stepu Ukrainy // Naukovi dopovidi Natsionalnoho universytetu bioresursiv i pryrodokorystuvannia Ukrainy. 2016. Issue 5. URL: http:/ nbuv.gov.ua/UJRN/Nd 2016516 (Last accessed: 12.05.2018)

7. Logachev A. V., Zapletina A. V., Bastron A. V. Study of the effect of presowing treatment of seeds of green crops of uh energyin the laboratory germination // Vestnik KrasGAU. 2017. Issue 1. P. 77-85.

8. Effects of Gamma Irradiation on Agromorphological Characteristics of Okra (Abelmoschus esculentus L. Moench.) / Asare A. T et. al. // Advances in Agriculture. 2017. Vol. 2017. P. 1-7 doi: http://doi.org/10.1155/2017/2385106

9. Bereka O. M. Obrobka nasinnia silskohospodarskykh kultur v sylnomu elektrychnomu poli. Kyiv: TsP «KOMPRYNT», 2011. 335 p.

10. Shherbakov K. N. Stimulyatsiya rostovykh protsessov rasteniy nizkoenergeticheskim magnitnym polem // Mekhanizatsiya i elektrifikatsiya sel'skogo khozyaystva. 2002. Issue 7. P. 26-29.

11. Petrovskyi O. M. Vyznachennia naibilsh prydatnoho diapazonu elektromahnitnoho vyprominiuvannia dlia peredposivno obrobky nasinnia // Visnyk Poltavskoi derzhavnoi ahrarnoi akademii. 2011. Issue 1. P. 163-165

12. Isaev A. V., Bastron A. V., Meshheryakov A. V. Effektivnye rezhimy predposevnoy obrabotki semyan rapsa $\mathrm{v}$ elektromagnitnom pole sverkhvysokoy chastoty: monograph. Krasnoyarsk: Krasnoyarskiy GAU, 2017. 146 p.

13. Chervinskyi L. S., Romanenko O. I. Elektrofizychni metody peredposivnoi obrobky nasinnia // Naukovyi visnyk Natsionalnoho universytetu bioresursiv i pryrodokorystuvannia Ukrainy. Seriia: Tekhnika ta enerhetyka APK. 2013. Issue 184 (1). P. 137-144.

14. Chervyakov A. V., Kurzenkov S. V., Tsirkunov A. S. Analiz sposobov predposevnoy obrabotki semyan elektrofizicheskimi faktorami // Konstruirovanie, ispol'zovanie i nadezhnost' mashin sel'skokhozyaystvennogo naznacheniya. 2015. Issue 1 (14). P. 183-188.

15. Dudin G. P. Mutagennoe deystvie izlucheniya geliy-neonovogo lazera na yarovoy yachmen' // Genetika. 1983. Issue 10 P. $1694-1696$
16. Romanenko O. I., Chervinskyi L. S. Rezultaty poshukovykh doslidzhen kombinovanoho oprominiuvannia nasinnia // Naukovyi visnyk Natsionalnoho universytetu bioresursiv i pryrodokorystuvannia Ukrainy. Seriia: Tekhnika ta enerhetyka APK. 2012. Issue 174 (2). P. 206-209.

17. Semenov A. O., Kozhushko H. M., Sakhno T. V. Vplyv peredposadkovoho UF-oprominennia na rozvytok i produktyvnist kartopli // Visnyk Poltavskoi derzhavnoi ahrarnoi akademii. 2018. Issue 1 (88). P. 18-23.

18. Semenov A. O., Kozhushko H. M., Sakhno T. V. Analiz roli UFvyprominiuvannia na rozvytok i produktyvnist riznykh kultur // Svitlotekhnika ta elektroenerhetyka. 2017. Issue 2. P. 3-16.

19. The effect of gamma, Uv and microwave radiation on potato tubers / Tykhonov A. V. et. al. // Sovremennaya tekhnika i tekhnologii. 2016. Issue 11 (1). URL: http://technology. snauka.ru/2016/11/11072 (Last accessed: 15.12.2017)

20. Safaralikhonov A. B., Khudoerbekov F. N. The influence of the replant Uv-irradiation seeds of wheat for its further growth and transpiration intensity of leaves // Dokl. Akademii nauk respubl. Tadzhikistan. 2016. Vol. 59. Issue 7-8. P. 344-348.

21. Subramamon D. Effect of gamma radiation on the germination and seedling growth in French bean and Lima bean // Sei and Cult. 1981. Vol. 47. P. 107-108.

22. Jakubowski T., Pytlowski T. Impact of UV-C radiation on the infestation degree of the stored potato tubers with rhizoctonia solani kuhn // AIP Conference Proceedings Agricultural engineering. 2015. Vol. 2 (154). P. 35-43. doi: http://doi.org/ 10.14654/ir.2015.154.119

23. Kondrat'eva N. P., Krasnolutskaya M. G., Bol'shin R. G. UF svetodiodnaya obluchatel'naya ustanovka dlya obrabotki semyan pered posevom // Agrotekhnika i energoobespechenie. 2016. Vol. 1, Issue 4 (13). P. 22-31.

24. Rogozhin V. V., Kurilyuk T. T. Vliyanie malykh doz ul'trafioletovogo oblucheniya semyan na sostoyanie antioksidantnoy sistemy, prorastayushhikh zeren pshenitsy // Izvestiya TSKHA 1999. Issue 3. P. 105-124.

25. Savel'ev V. A. Obrabotka semyan pshenitsy ul'trafioletovymi luchami // Vestnik sel'skokhozyaystvennoy nauki. 1990. Issue 3. P. 133-135.

26. Moderate UV-A supplementation benefits tomato seed and seedling invigoration: a contribution to the use of UV in seed technology / Mariz-Ponte N. et. al. // Scientia Horticulturae. 2018. Vol. 235. P. 357-366. doi: http://doi.org/10.1016/ j.scienta.2018.03.025

27. Rogozhin V. V., Kurilyuk T. T. Vliyanie ul'trafioletovogo oblucheniya semyan na protsessy perekisnogo okisleniya lipidov v prorostkakh pshenitsy // Izvestiya TSKHA. 1997. Issue 3. P. 116-131.

28. Rupiasih N. N., Vidyasagar P. B. Effect of UV-C radiation and hypergravity on germination, growth and content chlorophyll of wheat seedlings // AIP Conference Proceedings AIP Conference Proceeding. 2016. Vol. 1719, Issue 1. P. 030035. doi: http://doi.org/10.1063/1.4943730

29. Romanenko O. I., Chervinskyi L. S. Metodyka rozrakhunku dozy ultrafioletovoho oprominennia nasinnia ohirka v ustanovtsi transporternoho typu // Pratsi Tavriiskoho derzhavnoho ahrotekhnolohichnoho universytetu. 2013. Vol. 4, Issue 13. P. 84-89.

30. DSTU-4138-2002. Nasinnia silskohospodarskykh kultur. Metody vyznachennia yakosti. Kyiv: Derzhspozhyvstandart Ukrainy, 2003. 173 p.

31. Bystrye i nadezhnye test-nabory dlya vyyavleniya GMO // Romer Labs. URL: https://www.romerlabs.com/ru/produkty/ test-nabory/gmo (Last accessed: 21.02.2018)

32. Sampling Rules N.124. Rules for sampling, Analysis instructions, Methods of analysis and certification: (Incorporating the Methods of Analysis Form No. 130). Gafta (The Grain And Feed Trade Association 9 Lincoln's Inn Fields). London: WC2A 3BP, 2012. 18 p.

33. Semenov A. O., Kozhushko G. M., Balja L. V. Non-ozone germicidal lamps for units of photochemical and photobiological action // Technological audit and production reserves. 2015. Vol. 4, Issue 1 (24). P. 4-7. doi: http://doi.org/10.15587/ 2312-8372.2015.46953

34. MVU 11-038-2007. Dzherela ultrafioletovoho vyprominiuvannia: metodyka vykonannia vymiriuvan parametriv ultrafioletovoho vyprominiuvannia. Kharkiv: NNTs «Instytut metrolohii, 2007. 33 p. 
35. Torfiani substraty. URL: http://kardash.com.ua/produkty_ua_ universal.htm (Last accessed: 13.12.2017)

36. Semenov A. A., Kozhushko G. M., Sakhno T. V. Device for germicidal disinfection of drinking water by using ultraviolet radiation // Vestnyk Karahandynskoho unyversyteta. Seryia «Fyzyka». 2016. Issue 1 (81). P. 77-80.

37. Semenov A. O. Kozhushko H. M. Device for germicidal air disinfection by ultraviolet radiation // Eastern-European Journal of Enterprise Technologies. 2014. Vol. 3, Issue 10 (69). P. 13-17. doi: http://doi.org/10.15587/1729-4061.2014.24822

Semenov Anatoly, PhD, Associate Professor, Department of Commodity Studies, Biotechnology, Expertise and Customs, Poltava University of Economics and Trade, Ukraine, e-mail: asemen2015@gmail.com, ORCID: http://orcid.org/0000-0003-3184-6925

Kozhushko Gregory, Doctor of Technical Sciences, Professor, Depart ment of Commodity Studies, Biotechnology, Expertise and Customs Poltava University of Economics and Trade, Ukraine, ORCID: http:// orcid.org/0000-0002-7306-4529

Sakhno Tamara, Doctor of Chemical Sciences, Professor, Department of Commodity Studies, Biotechnology, Expertise and Customs, Poltava University of Economics and Trade, Ukraine, e-mail: sakhno2001@gmail.com, ORCID: http://orcid.org/0000-0001-7049-4657 